\title{
New species of the genus Thinodromus Kraatz, 1857 from New Guinea (Coleoptera: Staphylinidae: Oxytelinae)
}

\author{
Новый вид рода Thinodromus Kraatz, 1857 \\ из Новой Гвинеи (Coleoptera: Staphylinidae: Oxytelinae)
}

\author{
M.Yu. Gildenkov \\ М.Ю. Гильденков
}

Smolensk State University, Przhevalsky str. 4, Smolensk 214000, Russia. E-mail: mgildenkov@mail.ru
Смоленский государственный университет, Пржевальского 4, Смоленск 214000, Россия.

KEY WORDS: Coleoptera, Staphylinidae, Thinodromus, new species, Australian biogeographic area, Indonesia, New Guinea.

КЛЮЧЕВЫЕ СЛОВА: Coleoptera, Staphylinidae, Thinodromus, новый вид, Австралийская биогеографическая область, Индонезия, Новая Гвинея.

ABSTRACT: Thinodromus (s.str.) bimeensis, sp.n. from New Guinea (Indonesia) is described.

РЕЗЮМЕ: Описан новый вид Thinodromus (s.str.) bimeensis, sp.n. с Новой Гвинеи (Индонезия).

\section{Introduction}

The article is a continuation of the author's work on the study of the fauna of the genus Thinodromus of the Oriental region [Gildenkov, 2017, 2018a, b, 2019a, b, 2020, 2021] and, in particular, Indonesia [Gildenkov, 2020, 2021].

This paper is based on the specimens deposited in the following collections: NHMW - Naturhistorisches Museum Wien (Austria); FMNH - Field Museum of Natural History (Chicago, USA). In the present study, standard methods were used for the taxonomic research of insects; the preparations were made on an MBS-10 binocular microscope. The genital preparations were processed using $10 \% \mathrm{KOH}$ and then fixed in euparal. In the descriptions and diagnoses giving the length to width ratio for the head, pronotum, and elytra, the following standard units were used: 7 standard units $=$ $0.1 \mathrm{~mm}$; thus, 1 standard unit constitutes about 0.0143 mm. Photographs were taken with a Canon EOS 5D Mark III camera and a Canon MP-E $65 \mathrm{~mm}$ objective using the extended focus technology.

The new species is described from Indonesia, from the island of New Guinea and, in terms of its distribution, belongs to the Australian biogeographic area. However, it is quite similar to Thinodromus (s.str.) shavrini Gildenkov, 2020 described [Gildenkov, 2020: 151] from the Philippines and Thinodromus (s.str.) kelabitensis Gildenkov, 2021 described [Gildenkov, 2021: 43] also from Indonesia, island of Borneo. From New Guinea (Papua New Guinea, Fly River), only one species of this genus was known [Herman, 2001: 1770] — Thinodromus latipennis (Fauvel, 1879), which is similar to the new species, but well distinguished by its large body size $(4.5-5 \mathrm{~mm})$ and distinct punctation of pronotum and elytra [Fauvel, 1879: 81]. From the Australian region [Herman, 2001: 1761, 1769] are also known Thinodromus antarcticus (Bernhauer, 1920) and Th. inflatipes (Oke, 1933).

Thinodromus antarcticus has been described (Bernhauer, 1920: 5) from eastern Australia, Queensland (Cedar creek). Syntype (Figs 1-2): 1+, Australia, Queensland: with labels "Cedar creek" "Queensl. Mjöberg" "mars" "Trogophloeus antarcticus Brnh. Cotypus" "Lectotypus Trogophloeus antarcticus Bernhauer, 1920 | des. M. Gildenkov, 2016" "Carpelimus (Bucephalinus) antarcticus (Bernhauer, 1920) | det. M. Gildenkov, 2016" "Chicago NHMus M. Bernhauer Collection" (FMNH).

Despite the placed label, we believe that the designation of the lectotype is premature, there remains the probability of finding a more complete specimen, possibly a male. Size small ( $2 \mathrm{~mm})$. The colouration is lightbrown. At the base of pronotal disc, there is a welldeveloped horseshoe-shaped depression (Fig. 1) and a pair of depressions in the central part of disc that merge to form a single butterfly-shaped depression, as in many species of the genus Carpelimus, subgenus Bucephalinus. In our opinion, T. antarcticus (Fig. 1) belongs to Bucephalinus like Thinodromus arcitenens (Fauvel,

How to cite this article: Gildenkov M.Yu. 2021. New species of the genus Thinodromus Kraatz, 1857 from New Guinea (Coleoptera: Staphylinidae: Oxytelinae) // Russian Entomol. J. Vol.30. No.2. P.149-152. doi: 10.15298/ rusentj.30.2.07 
1905) from Java [Makranczy, 2014; Gildenkov, 2020]; this is also confirmed by the structure of the spermatheca (Fig. 2). However additional material is required, including male genitalia.

Thinodromus inflatipes is described from the south of Australia, Viktoria State, Warburton. It is well distinguished [Oke, 1933: 106-107] by its small size (2.75 $\mathrm{mm}$ ) and by the shape of impression on the pronotal disc (Fig. 3).

\section{Thinodromus (s.str.) bimeensis Gildenkov, sp.n.} Figs 4-7.

MATERIAL. Holotype, ơ, Indonesia, West Papua: with labels "IRIAN JAYA: 22.9.1993 Bime-Calab Gebiet Bime 1400m" "ca. $140^{\circ} 12^{\prime}$ E $04^{\circ} 20^{\prime}$ S, leg. M. Balke (16)" (NHMW). Paratypes: 1 웅 "IRIAN JAYA: 22.9.1993 Bime-Calab Gebiet Bime 1400m" "ca. $140^{\circ} 12^{\prime}$ E $04^{\circ} 20^{\prime} \mathrm{S}$, leg. M. Balke (16)" (NHMW).

DESCRIPTION (holotype). Length $3.5 \mathrm{~mm}$. Colouration brown. Integument slightly shining, body with fairly long light-coloured seta.

Head transverse, with a wide base, ratio of its length (from posterior margin of head to anterior margin of clypeus) to maximum width is about 23:40. Neck constriction prominent. Eyes large, convex, occupying almost entire lateral side of head; eye diameter in dorsal view about 3.5 times longer than temples, head widest across eyes (Fig. 4). Head surface with rather clearly, fine and dense puncturation. Diameter of punctures about 2.0 times smaller than diameter of eye facet. Distance between punctures slightly smaller than their diam- eter, interspaces smooth, slightly shining (Fig. 4). Antennae rather long, 1-9th antennal segments longer than their width; 10th — about as long as wide (Fig. 4).

Pronotum heart-shaped, reaches its greatest width after about $2 / 3$ of the length measured from the base, then narrowed (Fig. 4). Ratio of pronotum length to its maximum width about 37:48. Surface of pronotum with rather clearly, fine and dense puncturation. Diameter of punctures about 4 times smaller than diameter of the eye facet. Distances between punctures are significantly smaller than their diameter, interspaces smooth, slightly shining (Fig. 4). Base of pronotal disc with distinct horseshoe-shaped depression (Fig. 4); central part of disc with 2 symmetrical distinct weakly developed oval depressions.

Ratio of length of elytra to their combined width about 69:77. Elytra with clearly, fine and dense puncturation. Diameter of punctures is slightly larger than diameter of eye facet. Distance between punctures much smaller than their diameter, interspaces smooth, slightly shining (Fig. 4).

Abdomen with fine and rather dense puncturation. Aedeagus of characteristic structure (Figs 5-6).

Female. Sexual dimorphism absent, female morphologically similar to male. The colouration is darker than that of the holotype - dark-brown; legs and antennae brownish. Spermatheca of characteristic structure (Fig. 7).

COMPARATIVE REMARKS. The new species is very similar to Thinodromus (s.str.) shavrini Gildenkov, 2020 described from the Philippines, but distinguished by a wider body and less long antennae; reliably distinguished by the structure of the aedeagus, especially by the structure of

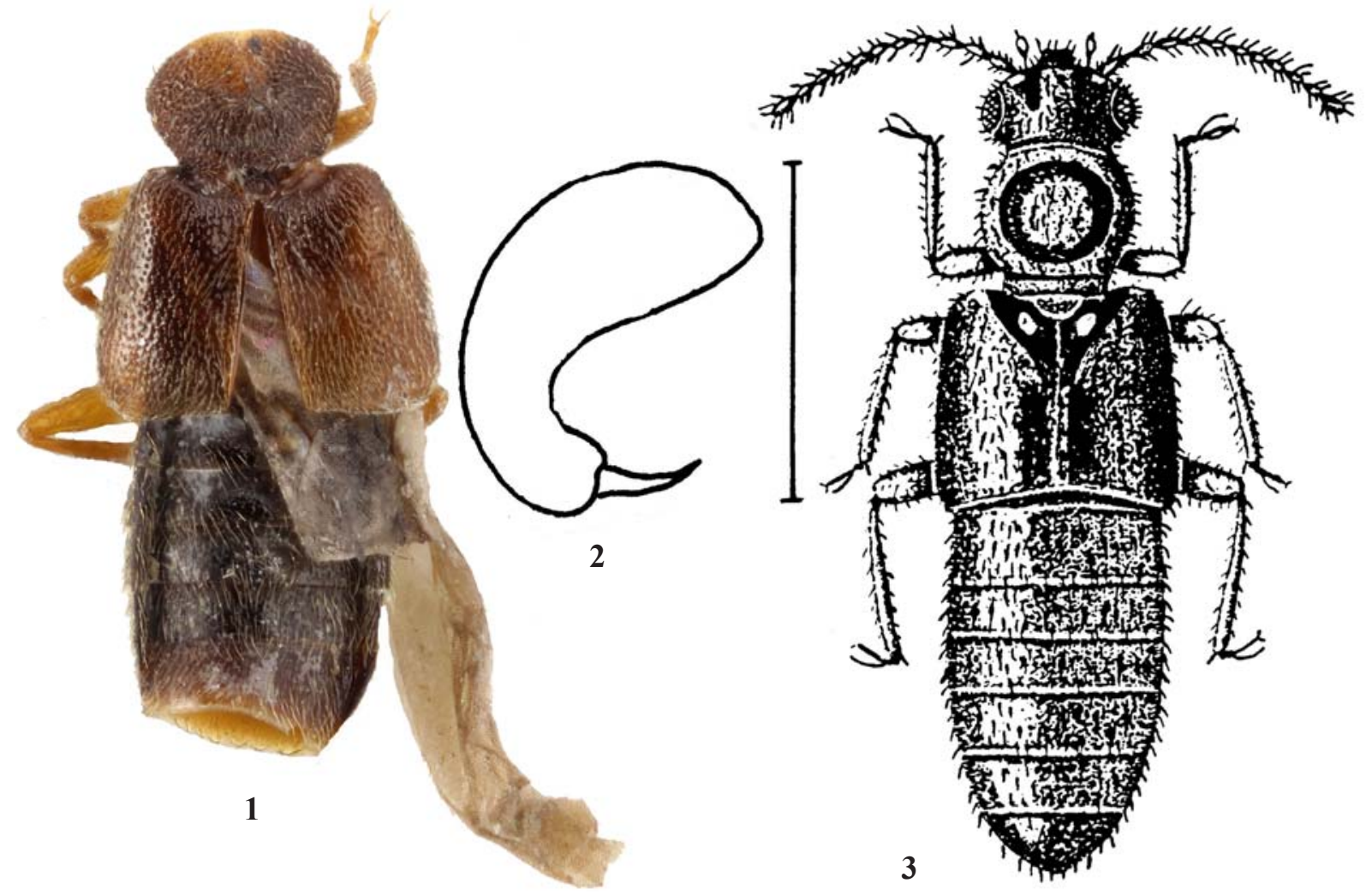

Figs 1-3. Thinodromus spp.: 1-2 - Thinodromus antarcticus (Bernhauer, 1920), syntyp, female (1 - habitus, dorsal view; 2 spermatheca; 3 - Thinodromus inflatipes (Oke, 1933), dorsal view (after Oke, 1933: 106, fig. 21). Scale bar: $0.1 \mathrm{~mm}$.

Рис. 1-3. Thinodromus spp.: 1-2 - Thinodromus antarcticus (Bernhauer, 1920), синтип, самка (1 - внешний вид, сверху; 2 сперматека); 3 — Thinodromus inflatipes (Oke, 1933), сверху [по Oke, 1933: 106, fig. 21]. Масштаб: 0,1 мм. 

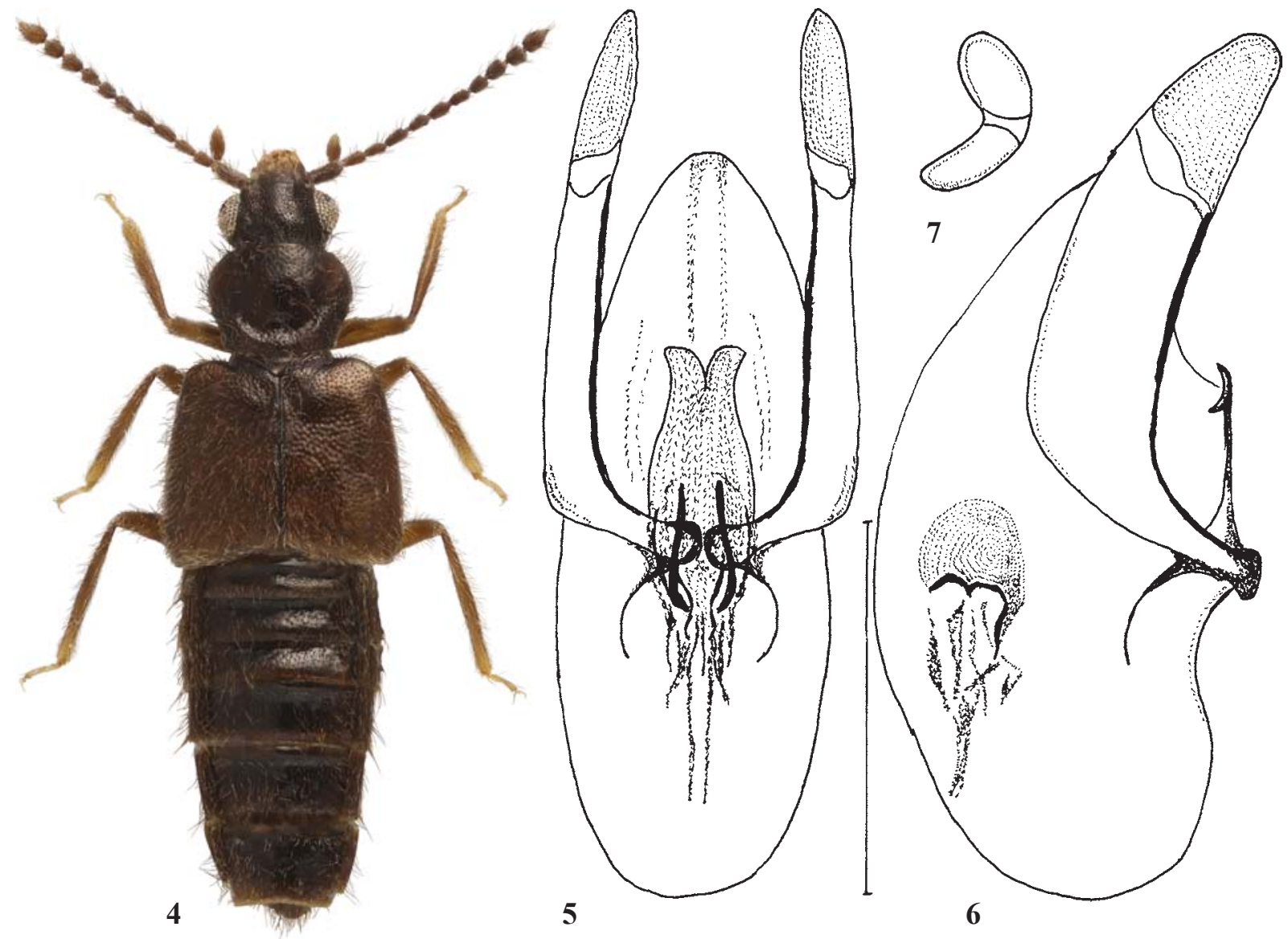

Figs 4-7. Thinodromus (s.str.) bimeensis, sp.n.: 4 - holotype, male, dorsal view: 5-6 - aedeagus, holotype (5 - ventral view; 6 lateral view); 7 - spermatheca, paratype. Scale bar: $0.25 \mathrm{~mm}$.

Рис. 4-7. Thinodromus (s.str.) bimeensis, sp.n.: 4 - голотип, самец, сверху: 5-6 - эдеагус, голотип (5 - снизу; 6 - сбоку); 7 сперматека, паратип. Масштаб: 0,25 мм.

parameres [Figs 5, 6; Gildenkov, 2020: Figs 10-11]. The new species is also similar to Thinodromus (s.str.) kelabitensis Gildenkov, 2021, described from Borneo, but distinguished by a wider body, less long antennae, smaller and denser puncturation of the head, pronotum, and elytra, and much denser puncturation of the abdomen. The new species is reliably distinguished by the structure of the aedeagus, especially by the structure of parameres [Figs 5-6; Gildenkov, 2021: Figs 3-4).

DISTRIBUTION. Indonesia, West Papua.

ETYMOLOGY. The new species is named due to its geographical distribution.

Acknowledgements. The author wishes to thank all colleagues for making material available for study: Harald Schillhammer (NHMW), Alfred F. Newton, Margaret K. Thayer and James H. Boone (FMNH). I also thank Kirill Makarov for taking the photos (Moscow Pedagogical State University, Russia).

\section{References}

Bernhauer M. 1920. Results of Dr. E. Mjöberg’s Swedish Scientific Expeditions to Australia 1910-1913. 22. Staphylinidae // Arkiv för Zoologi. Vol.13. No.8. P.1-27.
Fauvel A. 1879. Les staphylinides des Moluques et de la Nouvelle Guinée. (2e. Mémoire) // Annali del Museo Civico di Storia Naturale di Genova. Vol.15. P.63-121.

Gildenkov M.Yu. 2017. [A review of the Thinodromus lunatus species-group (Coleoptera, Staphylinidae)] // Zoologicheskii Zhurnal. No.96. No.10. P.1165-1180 [in Russian. English translation: Entomological Review. 2017. Vol.97. No.8. P.10891105].

Gildenkov M.Yu. 2018a. A new species of the genus Thinodromus Kraatz, 1857 (Coleoptera: Staphylinidae: Oxytelinae) from China // Far Eastern Entomologist. No.356. P.17-20.

Gildenkov M.Yu. 2018b. [Six new species of the genus Thinodromus Kraatz 1857 close to Thinodromus (Amisammus) ripicola (Cameron 1941) (Coleoptera, Staphylinidae, Oxytelinae)] // Zoologicheskii Zhurnal. No.97. No.11. P.1363-1373 [in Russian. English translation: Entomological Review. 2018. Vol.98. No.8. P.1113-1123].

Gildenkov M.Yu. 2019a. New species of the Subgenus Thinodromus Kraatz, 1857 (Coleoptera: Staphylinidae: Oxytelinae), from India and Nepal // Far Eastern Entomologist. No.381. P.15-20.

Gildenkov M.Yu. 2019b. [Three new species of the Thinodromus arcuatus group, genus Thinodromus Kraatz, 1857 (Coleoptera, Staphylinidae, Oxytelinae), from the Oriental region] // Zoologicheskii Zhurnal. No.98. No.11. P.1205-1212 [in Russian. English translation: Entomological Review. 2019. Vol.99. No.8. P. 1197-1204].

Gildenkov M.Yu. 2020. Three new species of the genus Thinodromus Kraatz, 1857 from Indonesia and the Philippines (Coleoptera: Staphylinidae: Oxytelinae) // Russian Entomological 
Journal. Vol.29. No.2. P.148-152.

Gildenkov M.Yu. 2021. Two new species of the genus Thinodromus Kraatz, 1857 from the Islands of Borneo and Sulawesi (Coleoptera: Staphylinidae: Oxytelinae) // Russian Entomological Journal. Vol.30. No.1. P.43-46.

Herman L.H. 2001. Catalog of the Staphylinidae (Insecta: Coleoptera). 1785 to the end of the second Millennium. // Bulletin of the American Museum of Natural History. Vol.265. No.3. P.1759-1776.

Makranczy G. 2014. Review of the Thinodromus circulus species group (Coleoptera: Staphylinidae: Oxytelinae) // Acta Entomologica Musei Nationalis Pragae. Vol.54. No.2. P.539- 554.

Oke C. 1933. Australian Staphylinidae // Proceeding of the Royal Society of Victoria. Vol.45. P.101-136. 